\title{
Blessing Same-Sex Unions in the Church of England: The Liturgical Challenge of Same-Sex Couples' Demand for Equal Marriage Rites
}

\author{
Rémy Bethmont ${ }^{1}$ \\ Email: remy.bethmont@univ-paris8.fr
}

(Received 17 January 2018; revised 20 January 2019; accepted 01 February 2019; first published online 08 July 2019)

\begin{abstract}
Those Anglican Churches that have opened marriage to same-sex couples have done so from a liturgical starting point which makes space for the eschatological vocation of marriage. Such liturgies are arguably more congenial to same-sex couples' demands for equal rites. The Church of England, on the other hand, has clung to services underpinned by a narrow view of marriage as a creation ordinance. It may be well-suited to the established Church's legal duties but it means that the present demand for the inclusion of same-sex couples into Christian marriage represents a greater challenge. Equal rites, however, need not exclude the view of marriage as a creation ordinance. Interviews with four Church of England clergy who have been involved in same-sex ceremonies allow an exploration of the kind of marriage services that would meet same-sex couples' demands and offer insights about what these demands say about the English marriage service today.
\end{abstract}

Keywords: Anglicanism, creation, Church of England, eschatology, established Church, homosexuality, liturgy, marriage, same-sex couples

Marriage equality, which became law in England and Wales by the 2013 Marriage (Same-Sex Couples) Act, reflects a major long-term shift in the British population, the overwhelming majority of which now supports same-sex marriage. ${ }^{2}$ This has created a gap between what the majority believe and the official position of the Church of

\footnotetext{
${ }^{1}$ Rémy Bethmont is Professor of History and Culture at the Département d'études des pays anglophones of the University of Paris 8 Vincennes - Saint-Denis, and head of the TransCrit research group.

${ }^{2}$ The British Social Attitudes 34 report from 2017 states that 64 per cent of the British population think that same-sex relationships are 'not at all wrong', up from 17 per cent in 1983 and 47 per cent in 2012 (http://www.bsa.natcen.ac.uk/media/39147/bsa34_moral_issues_final.pdf [accessed 3 January 2019]). And according to a Pew Research Center study based on Europe-wide surveys made between 2015 and 2017, 77 per cent of the UK population supports same-sex marriage (http://www.pewresearch.org/ fact-tank/2018/10/29/east-west-divide-within-the-eu-on-issues-including-minorities-gay-marriage-andnational-identity/ [accessed 3 January 2019]).
} 
England on homosexuality, making the Church appear homophobic in the eyes of many, especially the young. Laudable statements recognizing the reality and repenting of Christian homophobia have been made by the Archbishop of Canterbury, ${ }^{3}$ and the House of Bishops recently expressed its desire to establish 'across the Church of England a fresh tone and culture of welcome and support for lesbian and gay people, for those who experience same sex attraction, and for their families'. ${ }^{4}$ These are attempts to signal the Church's desire to include gays and lesbians as much as possible without endangering church unity. These attempts, however, have not yet been successful in ridding the Church of its homophobic image in the British public.

This is to be put down, to a large extent, to the fact that the Church of England has found it impossible thus far to make any decisive move over the question of the liturgical celebration of same-sex unions. Marriage equality has become a potent symbol of the shift towards a non-homophobic culture in much of the West and the Church of England's inability to claim that symbol makes its condemnation of homophobia look weak, if not hypocritical, in the eyes of many. Not only is marriage according to the rites of the Church of England closed to same-sex couples, but no liturgy acknowledging or celebrating same-sex unions has been authorized by General Synod or commended by the House of Bishops. Only some form of 'guidance' on what clergy's informal prayers for same-sex couples should consist in has been promised, 'for the protection of clergy and others ... specifying what may not take place and offering advice about what may, ${ }^{5}$ beyond the explicit ban on services of blessing. ${ }^{6}$

This situation has been explained by a combination of factors, notably the conservative doctrinal instincts of a majority of bishops and their concern about what a more liberal attitude to homosexuality would mean for the Mother-Church of the Anglican Communion, given the opposition of the 'Global South' to gay rights.7 These are extremely important factors. In this paper, however, I would like to focus on the liturgical factor as an additional explanation for the current Church of England difficulties in coming to terms with the increasing support for the full inclusion of gays and lesbians in the Church in the age of marriage equality. I would also like to suggest, however, that these difficulties can be overcome and that those, both clergy and lay, who have been involved in the unofficial, irregular blessing of a same-sex union, whether civil partnership or marriage, can offer useful insights in that respect.

\footnotetext{
${ }^{3}$ Andrew Brown, 'Justin Welby Gets Real on Homophobia', The Guardian, 28 August 2013, https://www. theguardian.com/commentisfree/andrewbrown/2013/aug/28/justin-welby-homophobia-anti-gay-prejudice (accessed 11 January 2019).

${ }^{4}$ House of Bishops, 'Marriage and Same-Sex Relationships after the Shared Conversations: A Report from the House of Bishops', General Synod of the Church of England, GS2055, January 2017), p. 5 (https://www. gloucester.anglican.org/content/pages/documents/1485513614.pdf [accessed 11 January 2019]).

${ }^{5}$ House of Bishops, 'Marriage and Same-Sex Relationships', p. 9. The report explicitly rules out either authorizing or commending such liturgies.

${ }^{6}$ The ban on blessings was spelled out in 'Civil Partnerships: A Pastoral Statement from the House of Bishops of the Church of England' (July 2005), but that statement did not contain any recommendation on what informal prayers may consist of.

${ }^{7}$ See Mark Chapman's paper on the role of homosexuality as a condensation symbol in Anglican Communion politics, making a change of policy on same-sex unions particularly difficult, "'Homosexual Practice" and the Anglican Communion from the 1990s: A Case Study in Theology and Identity', in Mark D. Chapman and Dominic Janes (eds.), Same-Sex Love and Desire: New Approaches in History and Theology (Basingstoke: Palgrave Macmillan, 2018), pp. 187-208.
} 


\section{An Official Liturgy Whose Doctrine Makes Establishing Equal Marriage Rites More Difficult}

The small number of Anglican Churches which have authorized or are considering authorizing the liturgical blessing of same-sex unions or marriages do so from a liturgical starting point which is rather different from that of the English Church. American and Scottish Anglicans, who changed their marriage canons in 2015 and 2017 respectively, had both previously gone through extensive revisions of their marriage rites, either on an eschatological or on a trinitarian line. The same thing can be said of the Church of Canada, which started a synodical process which may lead to a change in its marriage canon in 2019. And Brazilian Anglicans, who opened marriage to same-sex couples in 2018 after introducing gender-neutral language into the marriage service of their new 2015 prayer book, had a 1987 marriage rite which was essentially a translation of the 1979 US service. Unlike these four churches, the Church of England has never substantially altered its sixteenthand seventeenth-century tradition - beyond downplaying procreation as the main goal of marriage in favour of companionship - in the latest revisions of the marriage rite. The theological rationale of the Church of England marriage services, as interpreted by the Church authorities, still rests on a narrow, seventeenth-century conception of marriage as a creation ordinance with no specifically Christian meaning. This rationale is a more difficult starting point to work with than the eschatological or trinitarian theology of the American or Scottish marriage services.

Just after a first wave of liturgical revision in the Church of England that climaxed in the publication of the Alternative Service Book in 1980, Anglican liturgical scholar Bryan Spinks published a very critical paper calling for the recovery of the specifically Christian meaning of marriage in the Church of England liturgy. When the Church of England, together with most of its ecumenical partners, was returning to ancient liturgical patterns in the revision of its Eucharistic liturgy, why was it, Spinks asked, that the marriage service in the Book of Common Prayer was still seen as incomparable and the tradition it represented as not to be improved upon? Starting with an examination of the Sarum rite, the most widely used rite in medieval England, Spinks underlines that the centrepiece of the marriage service had not been the exchange of vows (done at the church doors in the Middle Ages), but the nuptial Eucharist that took place immediately afterwards in the church. In other words marriage was celebrated by the most specifically Christian act of worship, setting the marriage in the context of the history of salvation:

Marriage may be 'from the beginning,' but since the beginning there has been the Fall, and the whole of human history now stands in the shadow - and the light - of the Cross. All marriages take place between the Resurrection and the Parousia, and we may assume that Christian men and women will be aware of this, and would wish to celebrate their marriage in this context. ${ }^{8}$

The 1549 and 1552 Books of Common Prayer did away with the proper prayers of the medieval marriage Eucharist and simply provided for the usual order of Holy

\footnotetext{
${ }^{8}$ Bryan Spinks, 'The Marriage Service in the Church of England: Some Liturgical Considerations', Liturgical Review (November 1981), pp. 90-112 (96).
} 
Communion to follow the order for Holy Matrimony. But the 1662 revision of the Prayer Book turned the Eucharist into an optional act of devotion by the newly-wed. From then on in Anglican tradition the Eucharist was something which one could add to the marriage service but which was not an integral part of it. Given the relatively narrow focus of the Prayer Book Eucharist on the Passion, the effect of the influence of late medieval eucharistic piety on the compilers of the first editions of the Prayer Book, ${ }^{9}$ one may understand why the Restoration revisers of the Book of Common Prayer conceived of the marriage liturgy and of the Eucharist as separate. The celebration of a creation ordinance and the commemoration of Christ's Passion must have hardly seemed inextricably linked.

The return to a broader, more patristic understanding of the Eucharist in the wake of the Liturgical Movement in the twentieth century has produced Anglican liturgies in which the Eucharist is the commemoration of the Passion, Resurrection and Ascension as well as an anticipation of the Parousia, the glorious advent of the Kingdom of God when Christ returns. This restores the ancient view of the Eucharist as the celebration of the whole of the Christian pilgrimage towards the new creation. The traditional eschatological bridal imagery of Christ and the Church can now as naturally find its place in the Eucharist as in a marriage liturgy celebrating a covenant of love striving to imitate and be a sign of Christ's union with his Church at the end of times. In view of the gradual recovery of the lost eschatological dimension of the Eucharist in the process of liturgical revision in the twentieth century, one may have expected some related impact on the marriage service.

This did not happen, something of which Spinks is very critical. The Church of England held on to a marriage service which, like the 1662 Order for Holy Communion, was entirely turned towards the past, albeit not of the Passion, but of the Creation narrative of Genesis 1 and 2. The significance of marriage therefore tended to be limited to an expression of the natural order, independently of the Christian story of salvation and new creation. Spinks quotes a striking pronouncement by the commission appointed to make recommendations for liturgical revisions in the 1970s, the Root Commission, which exemplifies what this excessive dependence of the marriage service on the creation narrative led to:

The Root Commission stated that 'there is no such entity as "Christian Marriage" except in the sense of the marriage of Christian men and women,' and the Anglican Church tends towards the view that marriage is a 'creation' ordinance, and 'does not derive from faith in Jesus Christ and membership of his Church'.10

Eventually the Series 3 services, the trial liturgies that constituted the stepping stones to the 1980 Alternative Service Book, did have an optional order integrating the marriage service with the Eucharist (including proper readings, a proper preface and a proper post-communion sentence), but as Spinks points out 'all this is to be

\footnotetext{
${ }^{9}$ See Gregory Dix, The Shape of the Liturgy (London: Dacre Press, 1945), pp. 621-25.

${ }^{10}$ Spinks, 'The Marriage Service in the Church of England', p. 96. The quotes are taken from Marriage and the Church's Task (GS 363; London: Church Information Office, 1978), p. 31.
} 
found at the back of the Wedding Service, almost as an appendix, and is clearly regarded as an exception from the usual marriage service.'. ${ }^{11}$

No progress had been made towards situating marriage within the Christian vocation, which is to be taken up in God's creative, redeeming work of making the whole creation new. A similar conception of marriage as that expressed by the Root Commission can be found in the 1999 teaching document on marriage by the House of Bishops, the latest teaching document on the matter:

Marriage is a gift of God in creation; and the marriage of unbelievers is as real, and often as enduring, as the marriage of believers. The words 'till death us do part' are not a special religious ideal; they describe the form of relationship that God has given to human beings as a natural endowment. ... Yet it is important that those who marry know the full extent of what they are doing. And Christians believe that that requires an understanding of the love that God has shown mankind in Christ, a love which marriage is called to reflect. Those who understand God's love to them will understand their own love as a part of God's work in the world. ${ }^{12}$

The bishops consider marriage as belonging to the order of nature, an order that is best understood by the eyes of faith. The Christian faith therefore provides the best tools to understand the reality of marriage in which all, believers and unbelievers alike, share. In its January 2017 report on the shared conversations on same-sex unions the House of Bishops recognized that something was missing in Church of England teaching and promised that a new teaching document would 'consider marriage in terms of vocation'. ${ }^{13}$

The theological continuity so far in restricting the Christian conception of marriage to a creation ordinance has unsurprisingly led to little substantial liturgical change of the kind called for by Spinks when the Alternative Service Book gave way to Common Worship in 2000. The order of service with Eucharist, including a set of proper prayers, is at least no longer the mere 4-page appendix it was in the Alternative Service Book and the first part of the order is now fully printed out. Nevertheless the order for marriage with Holy Communion comes second after the order without communion, in continuity with the Alternative Service Book. In spite of a Eucharistic marriage service being literally given more space, the idea that the marriage service without Holy Communion is the norm and the other the exception seems to have remained with the compilers of Common Worship. The meaning of marriage is still defined by its being part of the order of nature, with no added eschatological dimension.

\section{The Contrast with the North American and Scottish Marriage Liturgies}

Among the many reasons which prevent the Church of England debate over samesex marriage to move forward, the liturgical reason should not be overlooked. The

\footnotetext{
${ }^{11}$ Spinks, 'The Marriage Service in the Church of England', p. 103.

${ }^{12}$ 'Marriage: A Teaching Document from the House of Bishops' (September 1999), https://www. churchofengland.org/sites/default/files/2017-10/marriage\%20-\%20a\%20teaching\%20document.pdf (accessed 11 January 2019).

${ }^{13}$ House of Bishops, 'Marriage and Same Sex Relationships', p. 8.
} 
sense of marriage as a creation ordinance which is firmly encased in the official marriage services makes it a daunting task to include same-sex couples. The North American and Scottish Anglican Churches that have moved or are moving towards adopting an inclusive marriage canon have done so from a very different liturgical starting point; their marriage services had taken on board the patristic view of the Christian vocation as eschatological participation in the life of the Trinity leading creation to its renewal.

The Episcopal Church's 1979 Book of Common Prayer presents the marriage service as including the Eucharist by default (in however discreet a way) and this goes hand in hand with some budding sense of the Christian vocation of marriage. The notion of the married couple as a sign of Christ's love for the world is expressed in the prayers of the people, and the preface of marriage at the beginning of the Eucharist presents married love as 'an image of the heavenly Jerusalem' and relates it to Christ's love which makes 'the whole creation new. ${ }^{14}$ All these characteristics can also be found in the 1987 Brazilian service.

The 1985 Canadian marriage service in the Book of Alternative Services borrows from the 1979 American Prayer Book but also goes a little further. The celebration of the Eucharist is presented as 'desirable' when 'both bride and bridegroom are entitled to receive communion' ${ }^{15}$ making it clear that a Eucharistic marriage liturgy should be seen as the norm. Although the phrasing of the prayer over the gifts at the beginning of the Eucharist is more sober than in the American eucharistic preface of marriage, ${ }^{16}$ the prayers of the people develop the eschatological vocation of marriage more than the American prayer book does. ${ }^{17}$

The 2007 Scottish marriage service is quite different from its North-American counterparts. The language is more trinitarian than eschatological, but as in the American and Canadian rites, the effect is to move away from a conception of marriage as a creation ordinance and give it specifically Christian meaning. To quote the Scottish Doctrine Committee: 'The changes in the Marriage liturgy reflect a growing theological emphasis upon the ways which human love derives from, reflects and participates in divine love. This emphasis enables us to say that marital union enhances our communion with one another and with God, and that this is good for human flourishing and brings us closer to our future, eschatological hope. ${ }^{318}$

The American, Brazilian, Canadian and Scottish marriage services constitute the liturgical background to these Anglican Churches' journey towards changing their

\footnotetext{
${ }^{14}$ The Episcopal Church, Book of Common Prayer (1979), p. 381.

${ }^{15}$ Anglican Church of Canada, Book of Alternative Services (1985), p. 527.

${ }^{16 \prime} \mathrm{God}$ of the covenant, hear our prayer, and accept all we offer you this day. You have made $\mathrm{N}$ and $\mathrm{N}$ one in the sacrament of marriage. May the mystery of Christ's unselfish love, which we celebrate in this Eucharist, increase their love for you and for each other' (Book of Alternative Services, p. 535).

${ }^{17}$ A Almighty God, in whom we live and move and have our being, look graciously upon the world which you have made and for which your Son gave his life, and especially on all whom you make to be one flesh in holy marriage. May their lives together be a sacrament of your love to this broken world, so that unity may overcome estrangement, forgiveness heal guilt, and joy overcome despair' (Book of Alternative Services, p. 533).

${ }^{18} \mathrm{~A}$ paper laying out the theology of marriage as currently articulated through the Canons and Liturgy of the Scottish Episcopal Church, and exploring whether there is a case for change based on scripture, tradition and reason' (Doctrine Committee to the General Synod of the Scottish Episcopal Church, June 2015).
} 
marriage canon. From a liturgical point of view, the Church of England is in a rather different place.

One of the most potent ways of opposing the full inclusion of gays and lesbians in the Church has been thanks to a theological argument based on the fact that God created humanity male and female. According to this 'creation argument', the male/ female binary, which is seen as identical with the man/woman binary, is a clear indication of God's intention that marriage should be between one man and one woman. A same-sex relationship is therefore seen as an attempt to deny the goodness of God's perfect creation in the beginning.

Understandably, attempts to defend same-sex relationships theologically have tended to move away from considering their conformity to the order of creation in the beginning and focus almost exclusively on an eschatological or trinitarian grounding. (Same-sex relationships are justified by their ability to reflect kingdom values, give a foretaste of the new creation and/or reflect the mystery of self-giving trinitarian love. $)^{19}$

Since in traditional Anglican liturgies it is the preface to the marriage service that contains most of the doctrine of marriage as a creation ordinance, liturgies devised for same-sex couples have tended to either get rid of any formal preface or adopt a preface that largely leaves out references to the Genesis narrative. ${ }^{20}$ The liturgical gap between same-sex blessing liturgies as they have been written since the 1990s and the Church of England marriage services is therefore considerably greater than was the case in the three Anglican Churches that have either implemented or started the process to allow marriage equality.

\section{A Glimpse of Same-Sex Rites Already Taking Place at Grassroots Level}

However difficult the official liturgical starting point may be in the Church of England, this has not prevented clergy from unofficially conducting liturgies of blessing for same-sex couples in churches, halls and gardens, in spite of the House of Bishops' ban. These services provide helpful insights into what it means

\footnotetext{
${ }^{19}$ This eschatological approach has dominated queer theology, from James Alison to Eugene Rogers. See Rémy Bethmont, 'Homosexualité, loi naturelle et rapport à l'accomplissement eschatologique de l'humain: réflexions sur un aspect négligé du débat anglican sur l'homosexualité', Istina 58.2 (April-June 2013), pp. 185-97 and 'How Queer Can Christian Marriage Be? Eschatological Imagination and the Blessing of Same-sex Unions in the Episcopal Church', in Chapman and Janes, Same-Sex Love and Desire, pp. 209-25.

${ }^{20}$ I refer to liturgies made available on the Changing Attitude UK website, to various rites produced by American Episcopal dioceses and individuals before 2012 and to the home-made orders of service that several Anglican priests gave me. And I also refer to the liturgies found in the following books: Elizabeth Stuart, Daring to Speak Love's Name: A Gay and Lesbian Prayer Book (London: Hamish Hamilton, 1992), pp. 28-52; Jim Cotter, The Service of my Love: The Celebration and Blessing of Civil Partnerships (Aberdaron: Cairns Publications, 2009); Jeffrey Heskins, Unheard Voices (London: Darton, Longman and Todd, 2001), pp. 227-31; Geoffrey Duncan (ed.), Courage to Love: An Anthology of Inclusive Worship Material (London: Darton, Longman and Todd, 2002), pp. 291-98, 316-21. In the few liturgies which have retained a preface that evokes creation, the formulation is often very vague and cannot be seen as a successful deconstruction of the heteronormative readings of Genesis 2 . For example, the preface of the liturgy produced by the Episcopal diocese of Chicago says that the 'calling to live in the bond of a holy union is a gift from God, in whose image we are created' (The Witnessing and Blessing of a Holy Union, Episcopal Diocese of Chicago, provided for provisional use on 1 June 2011).
} 
to celebrate civil partnerships and marriages in the liturgical context of the Church of England and it is woeful that the present English church political atmosphere prevents what happens in these services and the lessons that can be drawn from them to be as fully part of the church conversation on same-sex marriage as they should be. This section is my attempt to underline the contribution that these samesex blessings can make to the debate in the Church of England.

In 2016 I set out to find clergy who had led same-sex ceremonies in response to same-sex couples who wanted a liturgical celebration of their union since civil partnerships were introduced in Britain in 2004. Most disappointingly, I was eventually able to speak with only four clergy. This small sample is a reflection of the difficulties I encountered in finding clergy who were willing to talk to me about their experience and views of same-sex liturgies.

These services are 'hush-hush' in the words of a priest who knew I was looking for clergy who were likely to have conducted same-sex ceremonies. The secrecy around them and the desire, described by a priest friend of mine to intentionally 'forget about it immediately' when you hear that a priest you know was involved in a same-sex ceremony, meant that merely knowing who to contact was a challenge. And the fear of adverse consequences if the officiant is found out is hardly an encouragement for a priest who has officiated at a same-sex ceremony to speak about it to a stranger.

All four priests I interviewed are male, three of whom are gay and partnered. I shall call them Revd Tim, Father Peter, Revd Kevin and Revd Stephen. All except Kevin have led a number of services for same-sex couples in the last ten years or so and Kevin spoke of ceremonies he attended as a guest as well as of his own. The four men have no particular connection to one another, at least to my knowledge, and I interviewed them on separate occasions in 2016.

To my disappointment, none of the female clergy I contacted answered my request. I had to be content with an all-male sample which displays some degree of diversity in terms of churchmanship although it excludes the low-church Evangelical type. Father Peter is a liberal Catholic, Revd Tim is of the liberal, middle-of-the-road variety, Revd Kevin is happy to be described as liberal Catholic or progressive and Revd Stephen as middle-of-the-road. The semistructured interviews lasted about an hour, except in the case of Revd Stephen, who granted me more than two hours. All quotes from the interviews in this paper have been checked with their authors for accuracy as well as for the sake of protecting their anonymity.

For all the inadequacies of this clerical sample, the conversations I had with the four men offer a wealth of insights about the contribution that same-sex blessings in the Church of England have to make about the broader meaning of marriage and its liturgical performance today. The liturgical demand from same-sex couples that the four priests have been faced with in the last decade is overwhelmingly about marriage and hardly about the kind of union specific to same-sex couples that the liturgical literature produced by queer theologians in the 1990s proposed to bless. ${ }^{21}$ Progressive though it is, the demand is also deeply traditionalist: it is about same-sex

\footnotetext{
${ }^{21}$ In the 1992 Daring to Speak Love's Name, for example, Elizabeth Stuart underlined that 'Very few lesbian and gay people would want to describe these ceremonies and the relationships they celebrate as "marriages.” ... Healthy and mature lesbian and gay relationships do not ape marriage' (pp. 18-19).
} 
couples experiencing the same thing that has resonated with countless generations of married Christians.

Together the four priests' reflections point towards two different liturgical paths down which the Church of England could go to respond to the demand for equal marriage rites ${ }^{22}$ and more generally to offer a marriage service that would not grate on the ears of many English people. Two of the four clergy reflected in ways that were far more consistent with the kind of marriage liturgies that the Episcopal Church and the Scottish Episcopal Church have had since 1979 and 2007, respectively. This certainly testifies to the discomfort the Church of England's liturgy - and the theology of marriage it reflects - may occasion in its clergy. One priest, however, did appear to conceive of marriage in a liturgical way that is consistent with the rationale of the current, authorized English marriage services. The theological vision of marriage as a creation ordinance in the Church of England's liturgical tradition may not be that insuperable an obstacle to devising liturgies that include same-sex couples.

\section{The New Demand for Equal Rites in the Marriage Equality Era}

All four priests indicated that all services of blessing they attended or officiated at were seen and discussed as marriages by the clergy involved, the couple themselves and their guests. Typically, Father Peter answered my question about the vocabulary that was used with and around the same-sex couples whose union he celebrated by saying that whereas

publicly it was a service of prayer and thanksgiving, privately we talked about marriage and wedding. The guests talked about 'the wedding.' In the reception hall, the decoration, everything was about a wedding. ${ }^{23}$

Interestingly, Father Peter made it clear that most of the ceremonies he talked about had taken place before marriage equality, when the couples he dealt with had in fact entered a civil partnership. As in secular society, understanding gay and lesbian relationships as marriages in the Church clearly predates the 2013 Marriage (Same-Sex Couples) Act. The Act has only made it more difficult to not see them as marriages, if we believe what Revd Kevin says about civil

\footnotetext{
${ }^{22}$ By equal rites, I mean a body of alternative marriage services that would be equally suitable to differentsex and same-sex couples. According to the constitutional arrangement agreed under the archbishopric of Michael Ramsey, which gave the General Synod legislative autonomy from Parliament on matters of doctrine and worship, the Book of Common Prayer is forever authorized as the liturgy of the Church of England (and will remain authorized unless one wishes to reopen the question of disestablishment - see Owen Chadwick, Michael Ramsey: A Life (Oxford: Oxford University Press, 1991), pp. 191-95). The thoroughly patriarchal 1662 marriage service and its gendered language ('this man and this woman') will therefore, in the current conditions of Establishment, continue to be authorized whatever the outcome of the debate on same-sex marriage. This should not be seen as a problem: the alternative marriage services of Common Worship already differ from the 1662 rite on the importance of procreation in the definition of marriage (to say nothing of marriage as 'a remedy against sin') and on the question of the wife's obedience and subservience to the husband enshrined in the 1662 vows. Authorizing alternative rites with gender-neutral language would merely add to an already existing list of very significant divergences.

${ }^{23}$ Interview notes, 1 November 2016.
} 
partnerships in the post-2013 era: 'nobody's doing [them] anymore, because people are getting married'. ${ }^{24}$ What Revd Kevin seems to indicate is that in the Anglican gay and lesbian constituency, it is only clergy like himself that continue to form civil partnerships because getting married would make it either difficult or impossible for them to continue to function as priests in the Church of England. ${ }^{25}$

This consensus between my four informants in seeing committed same-sex relationships as marriages is an indication that in the age of marriage equality in England, the time seems to have passed for the separate same-sex services that would have been so welcome in the early 1990s.

The liturgical celebration of a distinct gay and lesbian experience is something, arguably, that the House of Bishops in the Church of England today would probably be less reluctant to consider than equal marriage rites. It would be consonant with their stated wish to welcome same-sex couples as distinct from 'married' couples and to fight homophobia. But if we are to believe the four priests I interviewed, separate rites are hardly what same-sex couples who see their relationships as marriages demand: they want equal rather than separate rites.

Although a qualitative study such as this does not enable one to conclude that a massive shift in the gay and lesbian Anglican constituency has taken place towards conceiving of same-sex relationships as marriages, it seems reasonable to assume that the evidence collected for this study is at least indicative of some remarkable change since the 1990s. Unless one were to suppose that Anglicans are peculiarly counter-cultural, the statistical shift from civil partnerships to marriages that is visible in national surveys for England and Wales between 2013, when the Marriage Act was passed, and 2014 when it came into force is probably true for the Anglicans concerned too, ${ }^{26}$ even though there may well still be some Anglican same-sex couples who would not want their liturgy of blessing to be understood as a marriage.

\footnotetext{
${ }^{24}$ Interview notes, 4 November 2016.

${ }^{25}$ The very few priests who have married their same-sex partners since 2013 have had their licence to officiate removed if they were not in a freehold. And for a priest in a freehold, being in a same-sex marriage makes it impossible for him or her to move to another position within the Church. That priest is then condemned to either stay put or end his or her ordained ministry.

${ }^{26}$ Office of National Statistics figures indicate that 5646 civil partnerships were contracted in 2013 in England and Wales. In 2014, the year in which it became possible for same-sex couples to marry (from 29 March), the number of civil partnerships fell to 1683, far behind the 4850 same-sex marriages. In 2015, the first full year of lawful same-sex marriage, the number of civil partnerships further dropped to 861 and the number of same-sex marriages shot up to 6493. Although the number of civil partnerships in 2016 were up by 3.4 per cent compared with 2015, the fact that 49 per cent of those entering them were over 50 compared to 19 per cent prior to the implementation of marriage equality indicates that the younger generations of same-sex couples have overwhelmingly turned to marriage as the preferred legal framework for their relationships. Civil partnerships figures for 2017 confirm this trend. https://www.ons.gov.uk/ peoplepopulationandcommunity/birthsdeathsandmarriages/marriagecohabitationandcivilpartnerships/ bulletins/marriagesinenglandandwalesprovisional/2015\#more-females-than-males-married-a-partnerof-the-same-sex and https://www.ons.gov.uk/peoplepopulationandcommunity/birthsdeathsandmarriages/ marriagecohabitationandcivilpartnerships/bulletins/civilpartnershipsinenglandandwales/2016 (accessed 21 January 2019).
} 


\section{Finding the Right Balance between Continuity and Change in a Marriage Service that Is Available to All Couples}

The four priests interviewed have different views of how marriage, and sometimes more specifically same-sex marriage, can best be approached liturgically. The marriage service is a point of reference for all four, but in different ways. Although all agree that the preface to the official service which presents marriage as between one man and one woman must be changed, not all agree that more far-ranging change should be pursued.

Father Peter and Revd Kevin seem roughly satisfied with the official liturgy. 'I'm a traditionalist,' says Father Peter, 'writing vows yourself is very difficult. The traditional vows say what you need to say,' he adds, and speaks of their 'resonance'. In most cases, he simply uses one of the authorized marriage services with same-sex couples, 'playing a bit with the liturgy', rather than 'changing it'. By and large, this playing seems to involve making the preface inclusive. Father Peter is also happy with the same-sex couples he 'marries'27 writing their own vows, but his preference for the authorized services is clear.

In a similar vein, Revd Kevin describes the words of the Church of England's marriage service as 'a gift to the world':

They are beautiful and practical. They offer a vision for the future; especially the 1928 service or Common Worship. The vows 'for better for worse, for richer for poorer, in sickness and in health,' the words when you give the rings 'all that I am I give to you and all that I have I share with you'; you cannot say more than this. I've seen other vows written. Some are good. I like it when people write their own vows. But if you're speaking of an authorised liturgy that stands the test of time, the Church of England liturgy has it all.

Among the four informants, Father Peter and Revd Kevin spoke most about the political situation in the Church of England over the issue of same-sex marriage. Their own wish for marriage rites that are inclusive of same-sex couples seemed to reflect first and foremost a desire for 'equality', ${ }^{28}$ in Revd Kevin's terms. Their thoughts about the liturgical celebration of same-sex marriages focused on the need for inclusiveness and there was no demand for an official marriage rite that would represent a major revision of the existing services. Part of their liturgical 'traditionalism' may be explained by their acknowledgement of most couples' desire for a liturgy that resonates with what generations of couples have been doing. But resonance with the past can and does go hand in hand with reinterpreting the liturgy.

\footnotetext{
${ }^{27}$ Since the 2013 Marriage Act, on the Church's request, made it unlawful for a same-sex marriage to be validly celebrated and registered in the Church of England, these same-sex 'marriages' have no legal status. They amount to the blessing of a marriage after it has been legally entered in at the register office. In this sense, Father Peter cannot marry same-sex couples as he does opposite-sex couples.

${ }^{28}$ It should be noted that whereas the four priests shared the desire for equal rites, in the sense of rites that are equally available to same-sex and different-sex couples, they did not all see equality as part of the theological rationale justifying equal rites. Stephen in particular, contrary to Kevin, declared that 'equality is not a theological argument'.
} 
Speaking about a service he led for two women, Father Peter underlines the fact that the two brides insisted on having the traditional giving away of the bride that had been left out of the most recent liturgical revisions of the marriage service (although it is still available as an option):

Each girl walked the aisle with their father and mother. It couldn't have been more like a wedding. That was what the couple expected, what they wanted. The giving away of the bride was taken away in Common Worship, but in [the many] years of my ministry every single straight couple has asked for it to be put back. They want their fathers to be involved. They don't see this as patriarchal. Even when I explain where the custom comes from, they still don't care.

In the case of the lesbian wedding, of course, not only is the reinvention of the giving away of the bride on a non-patriarchal line evident, but the very possibility of a patriarchal understanding is made impossible. Far more than a heterosexual wedding ever could, a same-sex wedding makes evident how much the widespread desire for the experience of liturgical continuity in both same-sex and different-sex couples coexists with the widespread reinvention of the meaning expressed by the liturgy. Same-sex weddings only force one to acknowledge the discrepancy between the original meaning of the liturgy and what it has become for most if not all couples. What Father Peter's and Revd Kevin's comments suggest is that equal marriage rites need hardly be a liturgical revolution: they may only make explicit the way in which the traditional marriage service is already understood and practised by many straight couples.

Revd Stephen and Revd Tim approached the matter somewhat differently and seemed more inviting of broader liturgical change (which does not mean that they would disagree with Kevin or Peter about the need for experiential continuity through the ages). Revd Tim saw liturgies of same-sex blessings as experiments that should reflect back on different aspects of the official marriage services (not just the preface). He acknowledged the official marriage service as well as the Order for Prayer and Dedication after a Civil Marriage (the liturgy normally used for the marriage of divorced people) as his 'point of reference'. But he was also convinced of the need for liturgical experiments to offer back something that is missing in the official marriage services, for example 'recognising the freedom to grow as individuals'. He also commented on a blessing he did of a gay couple who were very much involved in the worshipping community: the ceremony took the shape of a Eucharist and the vows came close to reaffirming baptismal promises. ${ }^{29}$

\footnotetext{
${ }^{29}$ The first part of the promises, adapted from Jim Cotter in Elizabeth Stuart's Daring to Speak Love's Name, pp. 38-39, was made in the form of questions by the celebrant answered by the couple:

'N. and N., you are about to make a solemn promise. Do you believe God has called you to live together in love?

We do.

Do you promise to be loyal to each other, never allowing any other relationship to come before the one you are now to affirm?

We do.

Will you give yourselves wholeheartedly and without reserve?

We will.

Will you, under God, recognize each other's freedom to grow as individuals and allow each other time and
} 
Relating marriage to baptism is a departure from Church of England marriage services and echoes the work of the liturgical commission of the Episcopal Church in the States which gave rise to the 2012 liturgy of blessing for same-sex couples. ${ }^{30}$ Although Revd Tim did not explicitly advocate far-ranging changes in the official marriage services, his openness to change is indicated by his view of the usefulness of the liturgical experiments around same-sex blessings. If the Church of England eventually got round to considering the inclusion of same-sex couples into Christian marriage, then these experiments should inspire a new marriage rite that may look rather different from what the Church now has.

Revd Stephen is pleased enough with the sections relating to the making of the vows, the blessing of the rings and the blessing of the couple in the Common Worship marriage service. He chose to use them in his own service of blessing in church after his civil partnership some years ago and when presiding at other services for same-sex couples in church, he has allowed couples the option to use these authorized liturgical sections when they do not wish to devise their own liturgies. However, he is very critical of the marriage preface and his criticisms go far beyond its heteronormativity. This is related to Revd Stephen feeling uncomfortable about the strong sense indicated in the Preface that there may only be one marriage template 'which supposedly fits all':

Drawing on my long experience of preparing and marrying a wide range of couples there are clearly many different models of marriage being celebrated in church and increasingly outside of it. In God's kingdom, diversity and unity should go hand in hand. For example, I feel that I am married in the way that some people of the same sex feel that they are married, and that may not be like marriage for many straight couples. For example, my marriage does not involve the complementarity of the different sexes and nor does it involve their 'bodily union.' Bodily union, the Church tells us, is for procreation. Yet I have 'married' many older couples, gay and straight alike, where both parties are clear that they are a long way past any interest in 'bodily union'; and I have 'married' young couples, gay and straight alike, who do not wish to have children but who will be continuing a sexual relationship; and I have 'married' gay and straight couples with adopted children or children from surrogacy arrangements or from former relationships who want their children to grow up within a life-long, committed and loving faith context. The Preface, even in the Common Worship liturgy, remains cumbersome for people who don't want or cannot have children and that can sometimes cause pain and distress which needs to be worked through carefully during marriage preparation. ... I don't think [it] is appropriate ... to read out a shopping list of all that

space to do so?

We will.

Will you do all in your power to make your life together a witness to the love of God in the world? We will.'

${ }^{30}$ 'Faith, Hope and Love: Theological Resources for Blessing Same-Sex Relationships', in 'I Will Bless You and You Will Be a Blessing': Resources for the Witnessing and Blessing of a Lifelong Covenant in a Same-Sex Relationships (New York: Church Publishing, 2012), pp. 11-57 (33-50). Marriage, seen as a covenantal relationship, is related to the paschal mystery celebrated in the sacraments of Baptism and Eucharist. 
marriage might mean each time that I say the Marriage Preface. There ought to be several Prefaces for celebrants to offer to couples, like the range of prayers for use after the marriage, which reflect the different marriages people wish to enter into.

Stephen's remarks about the insufficiencies of the preface in its different incarnations (1662 BCP and Common Worship) and indeed of other sections in the liturgy, like the prayers, reflect some kind of synthesis between the sense of gay and lesbian specificities of the liturgies of blessing produced by queer theologians in the 1990s and the increasing tendency to see committed same-sex relationships as marriages. Although Stephen makes no mention of the 2007 Scottish marriage service, his wish for more liturgical options is effectively in line with what Scottish Anglicans have been practising in the last decade, albeit in a liturgy reserved to straight couples until 2016. The Scottish service, however, with its choice of three prefaces, seven thematic liturgies of the Word, two sets of vows and three blessings of the rings, represents a considerable departure from the tradition of the English Book of Common Prayer, both structurally and, as we have already made clear, theologically. Revd Stephen may not be advocating that much of a departure from the still recognizably Cranmerian services of the Church of England, but he is certainly in favour of a serious theological revisiting of the meaning of marriage, with corresponding changes brought to the marriage service. What a revised English marriage service would look like, however, is hardly possible to delineate with any degree of precision in a church political context that prevents, as Revd Stephen sees it, the greatly needed, collective theological conversation on the issue.

One should not conclude too hastily that my four informants displayed varying degrees of liturgical conservatism. Although this would hardly be surprising whenever liturgy is at stake, balancing out the continuity in which denominational identity is rooted and the changes needed to adapt to new insights and social realities is always a difficult exercise - the differences of approach displayed in the interviews with the four priests may simply reflect the fact that Tim and Stephen had given more thought than Kevin and Peter to the liturgical changes the official marriage services could benefit from. It is interesting to note that the liturgical traditionalism of Father Peter and Revd Kevin was seen more particularly in their love of the vows of the marriage service and, in Revd Kevin's case, the words said when the rings are given (something which is so bound up with the vows in the service that I wonder whether Father Peter would not also include them in what he saw as the great assets of the existing authorized services). Loving these particular liturgical formulations is not necessarily exclusive of openness to structural and theological changes in the liturgy as a whole. Equally, Tim's and Stephen's more radical approach does not exclude the appreciation displayed by Kevin and Peter of the 'resonance' of certain sections of the traditional services.

It is interesting that Revd Tim and Revd Stephen, who have most reflected on liturgical change, should have made suggestions that are in line with what the Scottish or the US-based Episcopal Church have done, bringing out the Christian meaning of marriage as a covenant taking its being from the baptismal covenant (in the American Episcopal Church) or as reflected in a multiplicity of 
Christian images related to trinitarian love giving Christian meaning to different types of marriages (in the Scottish Episcopal Church).

On the contrary Father Peter and Revd Kevin hardly got out of their ways to reflect on a specifically Christian meaning of marriage, although Father Peter did mention what he saw as the difference between a Christian and a non-Christian marriage, especially among gay people; the difference, he said, 'will turn out to be whether there is a commitment to faithfulness or not'. But he did not thereby define a specifically Christian meaning of marriage, grounded in the Christian vocation. Again, this may just be the result of Father Peter never having the occasion to reflect on this. But in Revd Kevin's case, there were some clear indications that his vision of church marriage was that of something whose meaning was not different from civil marriage:

Sacramentally, what makes a marriage is performative language. Whether you do it in a civil or religious building, what marries you is you and the words you say: 'let there be us, and there was us.' There is marriage happening. The tragedy is that we're not permitting people to have it in church.

Kevin's reasoning is in line with official Church of England doctrine: there is no specifically Christian meaning of marriage. Revd Kevin's ability to envision the use of the official marriage services, with minimal changes, for same-sex couples therefore indicates that it may be possible, though perhaps harder, for English Anglicans to find their way towards equal marriage rites that remain squarely in the English tradition and do not follow the American or Scottish lead. This would allow the Church of England to open marriage to same-sex couples while retaining continuity with its historic role of marriage validator by default and its legal duties as the established Church.

\section{A Doctrine of Marriage Paradoxically at Odds with the National Status and the Missional Imperatives of the Established Church}

As the established Church, the Church of England's role in the marriage business is quite different from that of churches such as the Scottish or the US-based Episcopal Church. Historically, it was the Church of England that married the English, irrespective of their religious beliefs or denomination. ${ }^{31}$ This legacy is still alive in English law; all opposite-sex couples in England, irrespective of their religious identity or status, have a legal right to marry in their parish church (or in a parish church with which they have some personal connection) as long as both members of the couple are free to marry. The only exception to this rule is when one or both members are divorced; in this case ministers have the freedom to decide whether or not they want to marry the couple.

To a large extent this legacy may explain the Church of England's reluctance, described in the first section of this paper, to abandon the non-eucharistic order for marriage as normative. In most church weddings celebrated today in the Church of England, the lack of commitment to the Christian faith in the couples concerned means that a Eucharistic marriage service is probably not the preferred option. It is therefore understandable that a marriage service without Holy

\footnotetext{
${ }^{31}$ Until the 1836 Marriage Act only Jews and Quakers could legally marry outside the Church of England.
} 
Communion should have been seen as the numerical norm. It need not, however, have been seen as a liturgical norm. If it has, it is because the meaning of marriage has been restricted to a creation ordinance. The Roman Catholic Church, which insists on the sacramentality and Christian meaning of marriage, also routinely marries couples whose connection to the Christian faith is very slim indeed. It has nevertheless insisted on considering a eucharistic marriage service as the norm, no matter how many exceptions have to be made for lapsed Catholics. ${ }^{32}$ As far as marriage goes, the Church of England's theological position is closely correlated to its legal duty to provide religious marriage rites for the English population at large. The Anglican marriage business is one of the last relics of the established Church's former status as religious department of state for all English people.

The irony, however, is that the English population the Church is supposed to marry seems to increasingly display an understanding of marriage which is no longer the 'natural' union of one man and one woman. This is something that came up very forcefully in the interviews I conducted with the four priests. They feel distinctly ill-at-ease with the gap that separates the marriage service from most of the couples whose marriage it is supposed to celebrate. I found their remarks all the more striking as my questions never brought up this particular topic.

Revd Tim and Revd Stephen both underlined that whereas most of the people getting married in the Church of England are 'not committed Christians' (in Revd Tim's words), all the same-sex couples they did a service for had asked for one for reasons related to their own ongoing journeys in faith. As Revd Stephen says: 'the real difference in the "marriage" services that I have presided at is not so much between the same-sex and the heterosexual services but between those for believers and those for the unbelievers'. He adds:

In the same-sex services that I have presided at, I was particularly struck by the depth of theological thinking, grappling and prayer over the different components of the service and their meanings which went on within the couples compared with my experience with the majority of heterosexual couples. Increasingly heterosexual couples are getting married in church because their family want this for reasons of tradition or because the church provides an attractive venue. Over the years I have married a few committed heterosexual church members and the same is the case here: you feel straight away just how different their service is - a service for believers. Interestingly, the same-sex marriage services have also always been the most biblically based services that I have presided at. In all of my weddings, I insist that couples select one Bible passage for their service and most select an extract from the Song of Songs and then a secular poem but in the same-sex marriage services there are normally at least two or three Bible readings and they tend to be deeply rooted in the Gospel values of forgiveness, charity and justice. One really is struck by how each and every part of the service has been creatively and prayerfully considered in these services. Indeed one cannot help but reflect that when the liturgy is not taken for granted or simply passively received, then it is experienced as truly transformative, meaningful and real.

\footnotetext{
${ }^{32}$ See Spinks, 'The Marriage Service in the Church of England', pp. 104-105.
} 
In its historic role of legal marriage validator, ${ }^{33}$ the Church of England mostly marries people with little connection to a worshipping community in an increasingly secular society. But ironically it refuses to celebrate the marriages of Christian same-sex couples who are very much part of the English minority who want to marry in church for specifically religious reasons. What is more, in a country which overwhelmingly supports marriage equality, most of those who marry in the Church of England find themselves at odds with the idea in the marriage preface of a creation ordinance bringing together one man and one woman. This makes Revd Kevin 'uneasy leading marriage services ... People in attendance don't believe that marriage is one man and one woman.'

Father Peter, for his part, points to the same problem of a widening gap over same-sex unions between the national Church and the society it says it wants to serve. He talks about his experience of blessing the civil partnership of a samesex couple on a council estate before 2013:

When we were back in the house, there was a huge party. Blacks, Whites, jobless, employed, all celebrating two lesbian women. When the Church says no to LGBT couples, they're also saying no to their families and friends, to a whole community.

This raises the question of who the national Church is supposed to serve: if it seeks to consistently continue in its historic role as the established Church, one of whose duties it is to be a legal marriage validator, then it will struggle to preserve a definition of marriage at variance from that now favoured by the majority of the population. More broadly the question of marriage constitutes a missional impediment, one element among others that prevents the Church from being taken seriously by the nation. This was something that three of the four priests I interviewed spontaneously underlined. Revd Kevin mentioned the declining Sunday attendance in Church statistics:

Part of it is an erosion of the Church's trustworthiness and the Church's attitude to LGBT folks is partly responsible. A young girl at church told me she thought the Church was immoral on this. People don't get it in the church in the UK. They think it's going to be good if we disagree well about LGBT people. But you'd never say that about race or even divorce. What would good disagreement about the inclusion of Black people look like? It would be unacceptable to speak like this.

\section{Reinventing Marriage as a Creation Ordinance}

Can the Church of England keep its vision of marriage as a creation ordinance in continuity with its historic legal role and at the same time reinvent it and offer equal

\footnotetext{
${ }^{33}$ One should note, however, that this historic role has shrunk considerably: in 2015 only 26 per cent of marriages between opposite-sex couples in England and Wales were religious marriages, down from 50 per cent in 1980. (https://www.ons.gov.uk/peoplepopulationandcommunity/birthsdeathsand marriages/marriagecohabitationandcivilpartnerships/bulletins/marriagesinenglandandwalesprovisional/ 2015\#religious-ceremonies-continued-to-decline-in-popularity)
} 
rites? In recent years queer readings of the Genesis narratives have multiplied, calling into question the conservative readings which insist on the narrowly gendered interpretation of the male/female binary in Gen. $1.27^{34}$ or depict the creation of Adam and Eve in Genesis 2 as the institution of a God-given heteronormativity. There may therefore be possibilities of developing equal rites with a theology of marriage as a creation ordinance that echo these queer readings.

Revd Kevin was particularly taken with what two friends of his did for their ceremony. They had approached their local vicar but he was nervous about anything happening in the church. So the ceremony eventually took place in their garden. The couple took advantage of this to decorate the garden in such a way that people might be reminded that 'it's not good for people to be alone'. The effect of this reference to God's words in the Garden of Eden (Gen. 2.18) was to root this same-sex ceremony in the creation narrative. The creation of the woman for the man by God in the Garden of Eden was now seen not as a divine injunction to heteronormativity but as the human quest for a partner in which God is of assistance. As Revd Kevin says about the ceremony: 'a garden was a good place to do it'.

Steven Greenberg's take on the Genesis narrative provides an exegetical justification for this kind of reading. Greenberg observes that in the creation narrative, 'God appears to be an artist, learning by trial and error': ${ }^{35}$

After every successful creative effort in the first chapter of the story, 'God saw, and behold it was good (tov).' At the very moment of fulfillment, as the tree of knowledge of good and evil is planted and protected and Eden is complete, God discovers a flaw in the plan. Something is unexpectedly 'not good' (lo tov). The first fly in the ointment of creation is human loneliness. Again the unpredictable consequences of creation are a surprise. The human created in the image of God is catapulted from playing in the garden to contemplating mortality. A single rule about a forbidden fruit has given birth at once to freedom, sin, and death. Suddenly Eden is a very lonely place.

Until now creation was to satisfy God. Until now only God could judge the outcome of things as good or not good. Now, the adam must be satisfied. It is assumed that the adam will know the fulfillment of desire, the end of aloneness when it comes, and will be able to judge what is 'good' when it is discovered. ${ }^{36}$

Greenberg refers to the fact that the suitability of Eve is never declared by God but by the adam (Gen. 2.23). There is therefore no divine command of heteronormativity in the biblical narrative but rather God's concern to bring his Creation to fulfilment in letting the adam decide who satisfies his desire for companionship.

\footnotetext{
${ }^{34}$ Queer readings underline that 'male and female he created them' does not only mean man and woman. It does not exclude the mix of male and female attributes in trans and intersex people or indeed in most if not all individuals.

${ }^{35}$ Steven Greenberg, Wrestling with God and Men: Homosexuality in the Jewish Tradition (Madison, WI: University of Wisconsin Press, 2004), p. 46.

${ }^{36}$ Greenberg, Wrestling with God and Men, p. 50.
} 
Occasionally some liturgies of blessing attempt to reclaim the Genesis narrative for same-sex couples. In the services he produced for the liturgical blessing of civil partnerships in 2009, Jim Cotter, notably, who often refers to God as creator in his liturgies, has a prayer of thanksgiving for Holy Communion which includes the image of the Creator bringing wholeness to the human heart by taking it out of its isolation. ${ }^{37}$

More boldly, perhaps, the proposed rite of blessing of the relationship of a same-sex couple after a civil marriage in the Anglican Church of Aotearoa, New Zealand and Polynesia, ${ }^{38}$ presented - and rejected - in General Synod in 2016, contains a preface that is very much in the tradition of marriage as a creation ordinance. It reads as a running commentary of Genesis 2 which deconstructs the heteronormative interpretation:

In the beginning, when God created the first human,

God declared that it is not good for us to remain alone.

Out of compassion, God created a companion

flesh of flesh and bone of bone,

so that two people could comfort and care for each other,

and thereby a pattern of mutual support and faithful partnership

was established from the very beginning. ${ }^{39}$

This is the liturgical translation by the commission who drafted the rite of an exegesis based on the work of Phyllis Trible ${ }^{40}$ (from which Greenberg also borrowed) which identifies 'the problem in Genesis 2' as 'aloneness'. ${ }^{41}$

It must be noted, however, that the New Zealand commission does not narrow the meaning of marriage down to a creation ordinance. Next to it, it also develops the eschatological vocation of marriage ${ }^{42}$ in ways that echo the arguments developed in the theological resources produced by the US Episcopal Church in $2012^{43}$ alongside the liturgy for the blessing of same-sex relationships. A reinterpretation of marriage on a non-homophobic line as a creation ordinance was therefore not the only basis on which the proposed New Zealand rite was drafted.

The Church of England is not closed to the idea of enlarging its theology of marriage. As I remarked earlier, in their 2017 report on the shared conversations on same-

\footnotetext{
${ }^{37}$ Cotter, The Service of my Love, p. 48.

${ }^{38}$ The proposed rite attempted to overcome the kind of difficulty the Church of England finds itself in. The New Zealand Church retains a traditional doctrine of marriage as between one man and one woman but cannot ignore the fact that many of its members consider the civil marriages of same-sex couples as real marriages that the Church should bless. The 2016 proposal is a blessing of the same-sex relationship that the New Zealand civil authorities (but not the Church) call marriage when a civil marriage has been contracted. The civil marriage would thus be blessed without having to define it as marriage in church law. In 2018 the Synod eventually allowed the blessing of civil same-sex marriages but did not authorize the 2016 proposed liturgy.

${ }^{39}$ A A Way Forward / He Anga Whakamua / Na Sala ki Liu: Recommendations to General Synod / te Hīnota Whānui 2016. Processes and structures relating to the blessing by Anglican priests and bishops in the Province of the Anglican Church of Aotearoa, New Zealand and Polynesia of relationships where a civil marriage has occurred. The Report of the Working Group formed by General Synod / te Hinnota Whānui, 2014' (Anglican Church of Aotearoa, New Zealand and Polynesia, 2016), p. 38.

${ }^{40}$ Phyllis Trible, God and the Rhetoric of Sexuality (Philadelphia: Fortress Press, 1978), pp. 90-99.

${ }^{41 ' A}$ Way Forward', p. 17.

${ }^{42 ‘}$ A Way Forward', pp. 16-22.

${ }^{43}$ Faith, Hope and Love', pp. 13-57.
} 
sex unions, the House of Bishops pledged to publish a new teaching document on marriage which will consider marriage as a vocation. It is out of this pledge that the project called 'Living in Love and Faith: Christian teaching and learning about human identity, sexuality and marriage' has come into being, supervised by the Bishop of Coventry, Dr Christopher Cocksworth. It is expected to be ready for publication in Spring 2020. ${ }^{44}$ Considering marriage as a vocation may open up the Church of England's theology of marriage to eschatological considerations without relinquishing the reference to marriage as a 'gift of God in creation', as the preface puts it in Common Worship. This would allow for some continued theological justification for the established Church's legal obligations regarding marriage. But to take the same-sex marriage debate out of the present deadlock, paying attention to the lived experience of marriage and of marriage services is necessary. The present atmosphere in the Church of England resulting from the ban on the liturgical blessing of same-sex relationships and the uncertainty about how much in breach of Church discipline priests are when they celebrate any form of same-sex ceremony make it very difficult for those who see same-sex couples as truly married to share their insights and their attempts to revisit the Christian liturgical tradition on a non-homophobic line.

${ }^{44 ‘}$ Sexuality Review Shows its Hand’, Church Times, 4 January 2019, p. 2.

Cite this article: Bethmont R. (2019). Blessing Same-Sex Unions in the Church of England: The Liturgical Challenge of Same-Sex Couples' Demand for Equal Marriage Rites. Journal of Anglican Studies 17, 148-167. https://doi.org/10.1017/S1740355319000081 